\title{
The insulin receptor: signalling mechanism and contribution to the pathogenesis of insulin resistance*
}

\author{
H. U.Häring \\ Institute for Diabetes Research, Munich, FRG
}

\begin{abstract}
Summary. The insulin receptor is a heterotetrameric structure consisting of two $\alpha$-subunits of $\mathrm{M}_{\mathrm{r}} 135$ kilodalton on the outside of the plasma membrane connected by disulphide bonds to $\beta$-subunits of $M_{r} 95$ kilodalton which are transmembrane proteins. Insulin binding to the $\alpha$-subunit induces conformational changes which are transduced to the $\beta$-subunit. This leads to the activation of a tyrosine kinase activity which is intrinsic to the cytoplasmatic domains of the $\beta$-subunit. Activation of the tyrosine kinase activity of the insulin receptor represents an essential step in the transduction of an insulin signal across the plasma membrane of target cells. Signal transduction on the post-kinase level is not yet understood in detail, possible mechanisms involve phosphorylation of substrate proteins at tyrosine residues, activation of serine ki-
\end{abstract}

nases, the interaction with G-proteins, phospholipases and phosphatidylinositol kinases. Studies in multiple insulin-resistant cell models have demonstrated that an impaired response of the tyrosine kinase to insulin stimulation is one potential mechanism causing insulin resistance. An impairment of the insulin effect on tyrosine kinase activation in all major target tissues of insulin, in particular the skeletal muscle was demonstrated in Type 2 (non-insulin-dependent) diabetic patients. There is no evidence that the impaired tyrosine kinase response in the skeletal muscle is a primary defect, however, it is likely that this abnormality of insulin signal transduction contributes significantly to the pathogenesis of the insulin-resistant state in Type 2 diabetes.
Type 2 (non-insulin-dependent) diabetes mellitus is characterized by both an abnormality of insulin secretion and an insulin resistance of target tissues [1-5]. Cross-sectional and prospective studies suggest that insulin resistance of the skeletal muscle is one of the earliest events in the development of the disease, possibly a primary defect leading to the disease $[6,7]$. To analyse the pathogenesis of cellular insulin resistance at the molecular level a detailed knowledge of the mechanism of cellular insulin action is required. In recent years substantial new insights into the mechanism of insulin signalling have been made. Insulin action consists of a wide spectrum of different effects on metabolic and growth control of the target cells of the hormone. It is believed that all these different effects are initiated by the binding of insulin to the two isoforms of the insulin receptor in the plasma membrane, whereas a branching of signal transduction occurs at a post-binding or even post-receptor level. The existence of a specific insulin receptor was postulated as early as 20 years ago by the original studies of Freychet et al. [8], Cuatrecasas et al.

* Given as the Minkowski Lecture, EASD Meeting, Lisbon, Portugal 1989.
[9] and Kono et al. [10], who demonstrated specific saturable binding of ${ }^{125}$ I-labelled insulin to cell surfaces. Since then a large number of studies have been performed characterizing the structure and function of the insulin receptor. Major progress in the understanding of receptor function was made 9 years ago by the observation of Kasuga et al. [11] and other groups that the insulin receptor functions as a protein kinase. Meanwhile, many details about the signal flow through the receptor and about the post-receptor signalling mechanism have become known although many steps in this mechanism remain obscure. In this review present knowledge about the mechanism of transmembrane signalling through the insulin receptor kinase (IRK) shall be summarized and defects of the signal flow leading to insulin resistance in Type 2 diabetes in particular shall be discussed.

\section{Basic characteristics of transmembrane signalling through the insulin receptor kinase}

The insulin receptor is a heterotetramer comprising two $\alpha$ - and two $\beta$-subunits. The $\alpha$-subunit of 135 kilodalton $(\mathrm{kDa})$ is located on the outside of the plasma membrane, 


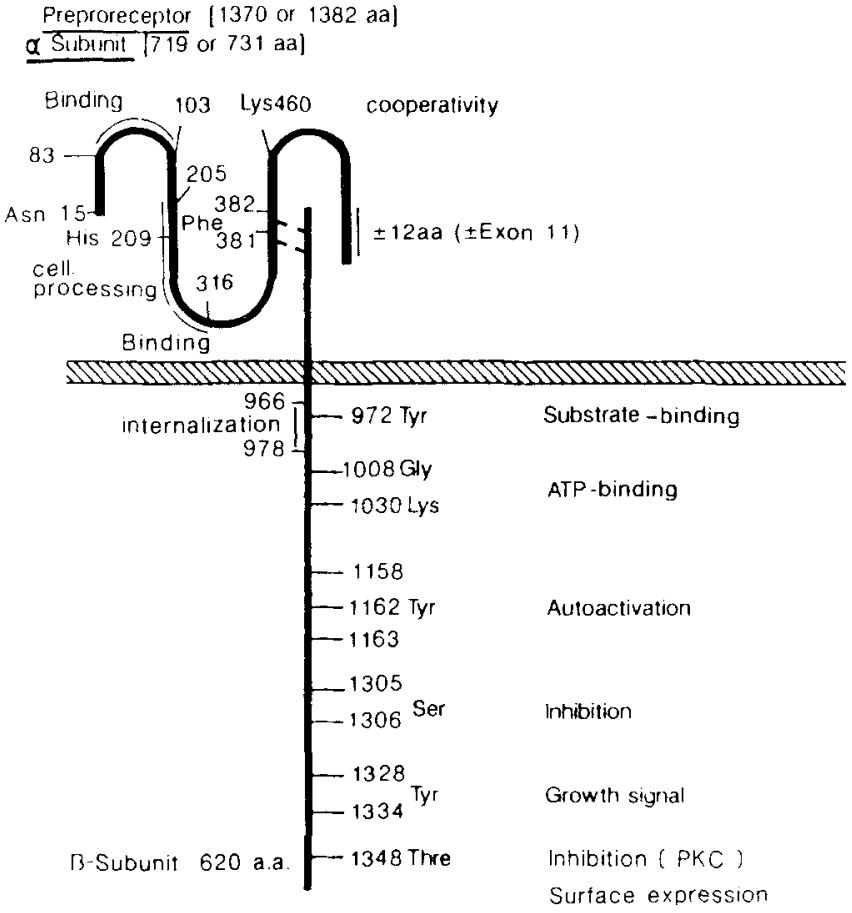

Fig. 1. Structure and functional domains of the insulin receptor. aa, amino acids; $\mathrm{PKC}$, protein kinase $\mathrm{C}$

linked by disulphide bonds to the $\beta$-subunit which is a transmembrane protein of $95 \mathrm{kDa}$. The $\alpha$-subunit of the receptor binds insulin. In intact cells insulin binding leads to phosphorylation of the $\beta$-subunit of the insulin receptor which occurs at tyrosine, serine and threonine residues $[12-16]$. The $\beta$-subunit of the insulin receptor contains an intrinsic tyrosine specific kinase. Insulin binding to the $\alpha$ subunit of the receptor activates the kinase in the $\beta$-subunit which then undergoes autophosphorylation [17-19]. It is believed that the further signal transduction occurs through tyrosine phosphorylation of other cellular proteins, which could transmit the insulin signal to the metabolic machinery of the target cell. Alternatively, it is speculated that the autophosphorylated receptor $\beta$-subunit may interact directly with regulatory proteins or with enzymes which could be modulated in a non-covalent way. The details of this process, as understood at present, will be described in the following sections.

\section{Functional domains of the insulin receptor (Fig. 1)}

It is now clear that the insulin receptor exists in two isoforms which contain $\alpha$-subunits of either 719 or 731 amino acids $[20,21]$. The insulin receptor gene contains 22 exons and it is now known that the length difference of the $\alpha$ subunit results from an alternative splicing of mRNA encoded by exon $11[22,23]$. Both types of the receptor termed HIR-A and HIR-B (HIR-A $=-12$ amino acids or - exon 11, HIR-B $=+12$ amino acids or + exon 11) are expressed at different tissues in different proportions [24]. The absence or presence of the 12 amino acid peptides in the $\alpha$-subunit determines different functional properties of the receptor [24]. This will be discussed in more detail at a later point. The $\alpha$-subunit of the receptor contains no transmembrane region, it is glycated and is entirely located on the outside of the cell [25]. For insulin binding the region of amino acids 83-103 [26, 27] and the so-called "cysteine rich region" (amino acids 205-316) are important $[28,29]$. The $\beta$-subunit of the receptor consists of 620 amino acids $[20,21]$. It contains a 194 amino acid extracellular domain which is glycated [25], a 23 amino acid transmembrane part, a 403 amino acid cytoplasmic sequence that contains a well-preserved tyrosine kinase domain similar to that found in several oncogenes (ROS, SRC, Dr BB2), and a unique C-terminal tail [20, 30-32]. The cytoplasmic sequence contains 13 tyrosine residues and it is believed that at least six of these tyrosines become phosphorylated after insulin stimulation [33-42]. Tyr ${ }^{972}$ (following the numbering of Ebina et al. [21] which counts through the sequence of HIR-B, including exon 11), is weakly phosphorylated $[39,40]$ and appears to be important for substrate binding [40]. The three tyrosines at 1158 , 1162 and 1163 in the preserved tyrosine kinase region contain $50-60 \%$ of the phosphate after insulin stimulation $[37,41]$, and are crucial for autoactivation [41]. The function of the tyrosines at 1328 and 1334, which contain $20-30 \%$ of the phosphate $[37,41]$ is not known. They are obviously not important for kinase activity, however, they might be related to growth signals [43]. The ATP-binding region of the receptor is located around Gly ${ }^{1008}$ and Lys ${ }^{1030}$ [44]. The function of the C-terminal tail of the $\beta$-subunit is also unclear as its removal does not alter kinase activity, endocytosis, degradation or binding properties [45-48]. It might, however, be the site of serine phosphorylation at amino acids 1305 and 1306 [49] and threonine phosphorylation at 1348 , which can inhibit the kinase activity through a conformational change. $\mathrm{Thr}^{1348}$ seems to be a major site for phosphorylation by protein kinase $\mathrm{C}$, and is probably important for regulation of receptor cell surface expression and turnover [50]. The juxtamembrane domain of the $\beta$-subunit spanning the 12 amino acids 966-977, which shows a high degree of homology with an analogous region of the LDL-receptor is required to allow the internalization of the insulin receptor and possibly the association with specific substrate proteins in the membrane $[51,52]$. Recently we obtained new data on the functional impact of the 12 amino acid peptide which determines the difference between HIR-A and HIR-B.

Beside the earlier described difference of binding affinities [24] we found a different tyrosine kinase activity of solubilized receptors [53] and different internalization kinetics of both receptor isoforms in fibroblasts [54].

\section{The binding step and signal transfer from the $\alpha$ - to the $\beta$-subunit: increasing evidence that conformational changes of the $\alpha$-subunit are transduced to the $\beta$-subunit}

Interactions between insulin and its receptor probably occur, as outlined above, at amino acids 83-103 and amino acids 205-316. It is speculated, that binding of insulin to its receptor induces a conformational change or a dimerization of receptor $\alpha$-subunits [55-59]. Very similar structural changes of the receptor molecule can be induced by cer- 

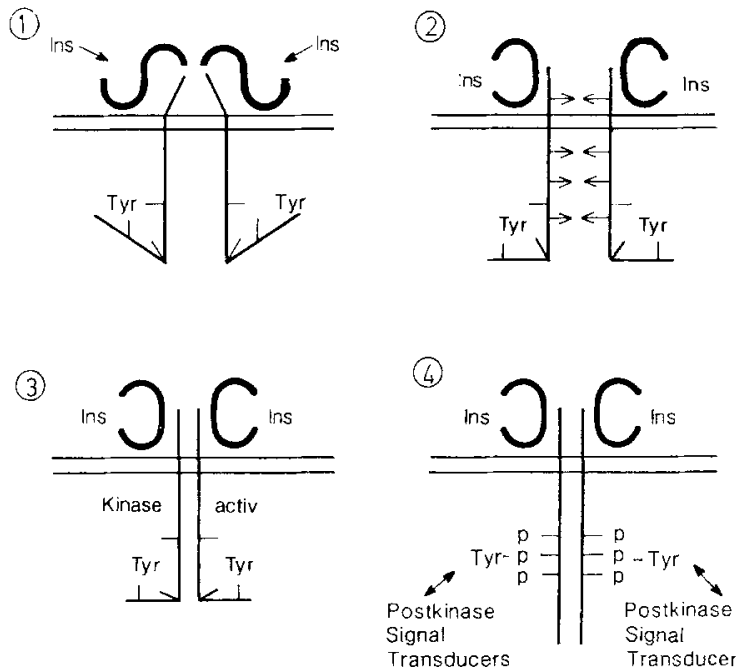

Fig. 2. Signal flow through the insulin receptor: insulin binding, conformational changes, activation of the tyrosine kinase, autophosphorylation of the $\beta$-subunit, interaction with post-kinase signal transducers. Ins, insulin

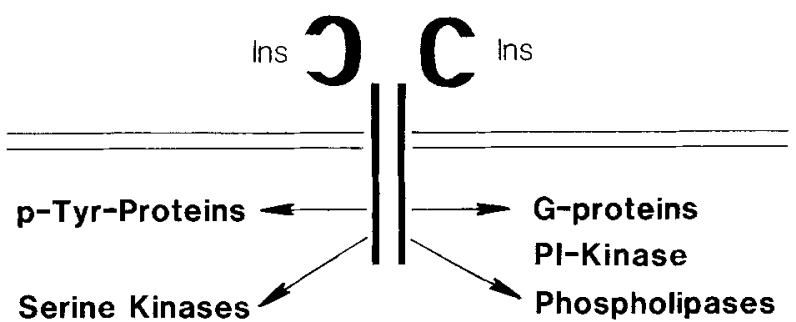

Fig.3. Postulated mechanisms of post-kinase signal transmission. Ins, insulin; PI kinase, phosphatidylinositol kinase

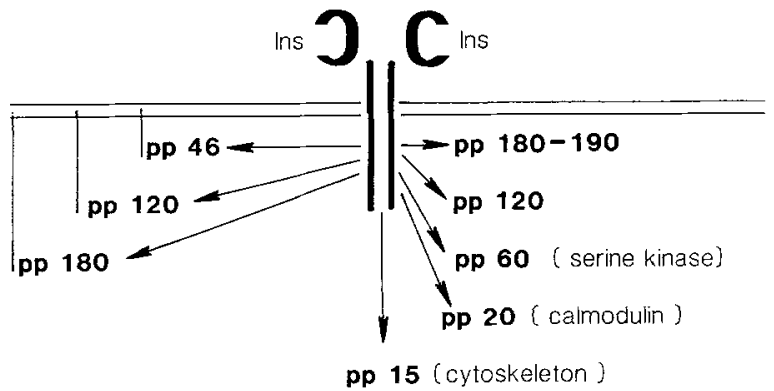

Fig.4. Mechanism of post-kinase signal transduction: tyrosine phosphorylated proteins (pp) which might be physiological substrates of the insulin receptor. Ins, insulin

tain insulin-like antibodies $[58,59]$. There is increasing evidence that the conformational change of the $\alpha$-subunit is transduced on the $\beta$-subunit and modulates the tyrosine kinase activity of the $\beta$-subunit. The coupling of the $\alpha$-subunit to the extracellular part of the $\beta$-subunit occurs through disulphide bonds. Tryptic cleavage experiments show that the amino acids which might be involved in the disulphide coupling are located in positions 432,468 or 524 of the $\alpha$-chain [60]. Following the idea that the unoccupied $\alpha$-subunit functions as an inhibitor of the $\beta$-subunit [61] it seems possible that the insulin binding-induced conformational change of the $\alpha$-subunit is transduced to the $\beta$-subunit and leads to relief from kinase inhibition
(Fig.2). Several recent findings support this interpretation: antibodies against specific regions of the $\alpha$-subunit are able to alter the kinase activity in the $\beta$-subunit [62]. Antibodies against the extracellular domain of the $\beta$-subunit can stimulate [62] or inhibit [63] the tyrosine kinase, pointing towards a role for the extracellular domain as a transducer element. Insulin binding to the receptor without autophosphorylation events results in conformational changes detectable in the kinase domain [64] as well as in the C-terminal part of the $\beta$-subunit [65]. When autophosphorylation occurs other types of changes can be detected in the C-terminus [65]. The possible functional importance of conformational changes is further underlined by the observation that ATP-binding to the $\beta$-subunit also causes a conformational change [64]. We recently obtained further support for such kinase modulation through the $\alpha$-subunit structure by comparing the same amounts of the two receptor types HIR-A and HIR-B which differ only in the sequence of the $\alpha$-subunit. We found that HIR-B exhibits in the solubilized form, but not in the intact cell, higher auto- and substrate phosphorylation activities [66], suggesting that the $\alpha$-subunit of HIR-A is a more efficient inhibitor of basal and insulin-stimulated kinase activity. Similarly, it was shown that a mutation at $P h e^{382}$ in the $\alpha$-subunit reduces the kinase activity of the $\beta$-subunit suggesting that in this case a conformational change of the $\alpha$-subunit also occurs which increases its inhibitory function [67].

\section{Autoactivation of the receptor kinase by tyrosine phosphorylation: the autophosphorylation cascade}

It appears that after kinase activation a signal amplification occurs through autophosphorylation. The crucial event for autoactivation of the receptor kinase is the phosphorylation of the tyrosine residues 1158, 1162 and 1163 [37-39, 41, 42]. It has been suggested that the phosphorylation of these three tyrosine residues occurs as an intramolecular autophosphorylation cascade, where the transition from a diphosphorylated to a triphosphorylated state represents the final activation step [41], most likely reflecting, a further allosteric change (Fig.2). The original idea of the autophosphorylation cascade was confirmed in several cell systems recently $[38,39]$. Furthermore, it is now clear that a transphosphorylation of receptor subunits can occur [68].

After activation of the insulin receptor and its intrinsic kinase the further signal transmission seems to branch into several different pathways involving the systems summarized in Figure 3.

\section{Post-kinase signal transduction: tyrosine phosphorylated proteins (Fig.4)}

For a long time the search for tyrosine phosphorylated proteins which might serve as a substrate for the insulin receptor kinase was unsuccessful. White et al. [69] were the first to use a phosphotyrosine-specific antibody to identify tyrosine phosphorylated proteins in the intact cell. They 


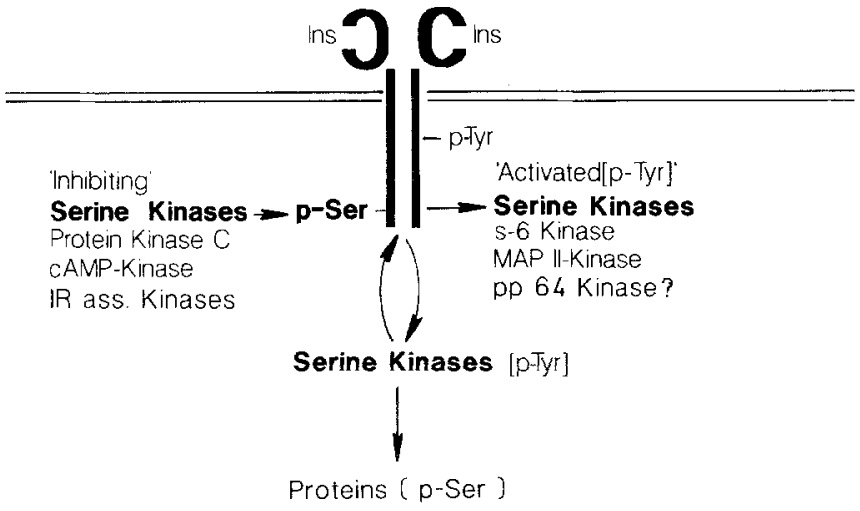

Fig.5. Mechanism of post-kinase signal transduction: interaction of insulin receptor (IR) and serine kinases. Ins, insulin

found a $185 \mathrm{kDa}$ protein in hepatoma cells which was rapidly phosphorylated on tyrosine residues after insulin stimulation of the cell [69]. In the meantime a number of different proteins [70-79] were identified which fulfilled the criteria of putative signal transmitting substrate proteins i.e. rapid phosphorylation in the intact cell stimulated by physiological insulin concentrations. We found proteins of $46 \mathrm{kDa}$ [70] and $180 \mathrm{kDa}$ [71] in the plasma membrane, both of unknown function. In the cytosol a number of bands were found. The originally described $185 \mathrm{kDa}$ protein was, meanwhile, found in many cells. Furthermore, a $115-120 \mathrm{kDa}$ protein is seen in many cell and membrane [71-73] systems. There is a $120 \mathrm{kDa}$ protein in hepatocytes [73], which appears to be a protein involved in bile-duct function [75]. In fat cells [70], hepatoma cells and transfected cells we found a $60 \mathrm{kDa}$ protein, which is particularly interesting as it might function as a serine kinase [80]. Furthermore, there is a $15 \mathrm{kDa}$ protein [76] which was identified as an abundant cell protein of the cytoskeleton [77]. In addition, calmodulin which is an in vitro substrate of the insulin receptor kinase [81-83], becomes phosphorylated in the intact cell. So far, signal transduction has not been demonstrated through any of these proteins with respect to specific insulin effects. Some progress might come perhaps from pp185, originally found by White et al. [69], as this protein was sequenced and cloned recently [84]. A function of this protein in coupling the insulin receptor to phosphatidylinositol kinase was proposed. This opens the possibility of generating specific antibodies which might be valuable tools for gaining further insight into the physiological and possibly also pathophysiological role of this substrate.

\section{Post-kinase signal transduction: insulin-stimulated serine kinase}

It is believed that the insulin receptor kinase might activate another serine specific kinase which has a dual function, namely further transduction of the insulin signal to other effector systems, and in a feedback mechanism, inhibition of the first steps of the insulin signalling at the level of the insulin receptor (Fig. 5). We, and others, have shown that serine phosphorylation, in particular by pro- tein kinase C and cAMP-kinase counteracts the effects of tyrosine phosphorylation i.e. it inhibits the signalling at the level of the receptor kinase [85-90] but also at a postkinase level [91].

The physiological significance of the serine phosphorylation might therefore, be a termination of the insulin signal or a mechanism to rapidly modulate the sensitivity of cells toward insulin signals. On the other hand it has been known for a long time that a number of enzymes are regulated by insulin through phosphorylation and dephosphorylation at serine residues [58]. Therefore, a signal transduction from the tyrosine-specific insulin receptor kinase (IRK) to a serine-specific kinase must occur. The serine kinase which might fulfil both functions in the insulin signal transduction chain has not yet been identified; however, there are several possible candidates for these so called "switch kinases". Beside the $60 \mathrm{kDa}$ protein described by us in fat cells [80], several serine kinases associated with the IRK, directed against the IRK or functioning as substrates of the receptor have been described [92-97]. More recently described candidates are the ras-oncogene kinase and the so called $\mathrm{KIK}=$ kemptide insulin sensitive protein kinase. The latter was isolated from rat liver and serves as an insulin signal transducer to ATP citrate lyase via phosphorylation events [97]. Several lines of evidence lead also to protein kinase $\mathrm{C}$ functioning as a switch kinase in insulin signal transduction as we, and others, have shown that stimulation of protein kinase $\mathrm{C}$ mimics several of the effects of insulin [98-103].

\section{Post-kinase signal transduction: phospholipid kinases}

A phospholipid kinase activity closely associated with but distinct from the insulin receptor [104-106] has been controversial. The question was whether it is insulin-stimulated or not. However, recently an insulin stimulation of such a phosphatidylinositol-3 (PI3) kinase in the intact cell was clearly demonstrated and the functional domain of the receptor $\beta$-subunit interacting with PI3 kinase was identified [107]. We have recently shown that both receptor isoforms HIR-A and HIR-B are able to stimulate PI3 kinase [108]. It appears possible that insulin-stimulated phospholipid phosphorylation plays a role in a signal transmitting system, which involves the activation of a phospholipase at a subsequent step, and the release of second messenger products from membrane phospholipids.

\section{Post-kinase signal transduction: guanosine-triphosphate (GTP)-binding proteins}

A role for GTP-binding proteins in post-kinase signal transduction has long been a topic for discussion. The evidence suggesting a role for G-proteins in insulin signalling consisted of the following: an effect of insulin on ADP-ribosylation was demonstrated [109-111], G-protein expression was found to be altered in streptozotocin-induced diabetes [112].

Furthermore, G-proteins serve in vitro as substrates for the insulin receptor kinase [111,113-115]. It is, however, 


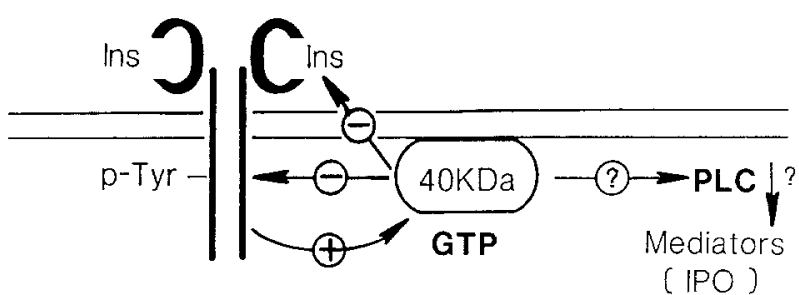

Fig. 6. Mechanism of post-kinase signal transduction: interaction of insulin receptor and a 40 kilodalton $(\mathrm{kDa})$ guanosine-triphosphatebinding protein (GTP), IPO, inositol phosphooligosaccharide; PLC, phospholipase C

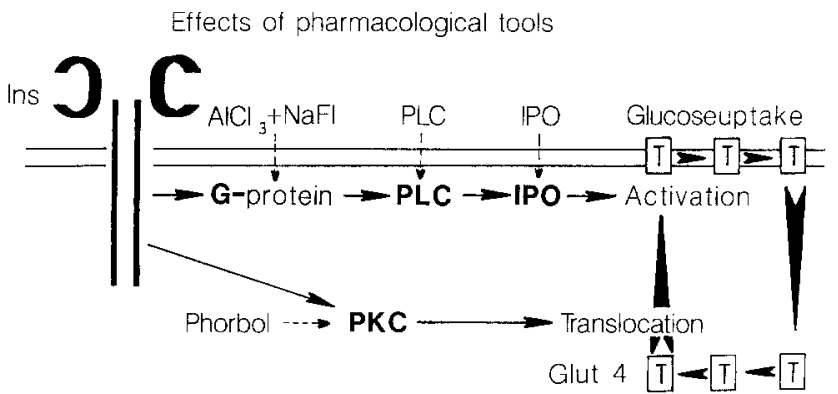

Fig. 7. Mechanism of post-kinase signal transduction: model of the signal flow to the glucose transport system in rat adipocytes. PLC, phospholipase C; IPO, inositol phosphooligosaccharide; PKC, protein kinase $\mathrm{C}$

important to note that such a role has not been observed in intact cells. Finally, G-proteins are able to modulate the insulin receptor kinase activity $[111,113]$.

New data have recently become available concerning the identification of G-proteins which interact with the insulin receptor. We have shown that stimulation of G-proteins produces insulin-like effects [116] and identified a $40 \mathrm{kDa}$ GTP-binding site in adipocytes, with distinct characteristics from $G_{r^{-}} \alpha$ and $G_{s}-\alpha$, which is activated by the insulin receptor [117]. McDonald and colleagues [118] also described a GTP-binding protein of a similar size which co-purifies with the insulin receptor. The molecular weight of this G-protein is also around $40 \mathrm{kDa}$, while a different susceptibility to cholera toxin and pertussis toxin was found. It is still unclear which effector systems might be activated by these G-proteins even though phospholipase $\mathrm{C}$ is a good candidate. It is, however, interesting to note that these insulin receptor associated G-proteins are able to inhibit the binding and kinase function of the insulin receptor possibly in a negative feedback sense [117].

\section{Post-kinase signal transduction: phospholipases and release of chemical mediators from membrane glycolipids (Fig. 6)}

Insulin action on phospholipase $\mathrm{C}$ has been a long-standing controversy. However, earlier reports on the stimulatory insulin effects on phospholipase $C[119,120]$ were more recently confirmed by others [121-123]. We could show that this putative insulin-activated phospholipase $\mathrm{C}$ is also under the negative control of protein kinase $\mathrm{C}$ [91] and may be activated by both receptor (HIR-A and HIR-
B) isoforms. It is believed that the substrates of these phospholipases are membrane glycolipids. By activation of the phospholipase C inositol-phosphooligosaccharides might be released from the plasma membrane. Despite many different effects of these inositol-phosphooligosaccharides on isolated cells and enzymes which have been described [124-132], their physiological role is still being discussed. As most of these glycolipids are located on the outside of the cell [132] this system might not be involved in intracellular signalling but might be important for cellcell signalling. Unfortunately even now exact structural data on these putative insulin second messengers are missing.

\section{Signal transduction to the glucose transport system: the fat cell model}

Despite increasing knowledge about the post-kinase signalling systems described above, the exact mechanism linking the insulin receptor to particular effector systems remains obscure.

One of the most important and intensively studied effector system of the insulin signal is the glucose transport system. Due to the work of Birnbaum et al. [133], Mückler et al. [134], Bell et al. [135] and others it is clear that five different isoforms of the glucose transporter protein exist. A classic cell model which was widely used to study the signal flow from the receptor to the glucose transport system is the isolated adipocyte where activation and deactivation of the glucose transport system can be easily studied $[136,137]$. Almost 10 years ago it was shown in this cell model by Cushman et al. [138] and Kono et al. [139] that insulin induces a translocation of glucose carriers from intracellular membranes to the plasma membrane. In the meantime data from many different groups, including our own, have suggested that a purely translocation model is not sufficient to explain the insulin effect $[99,116,140$ 144]. We, and others, suggest a combined model involving translocation and activation of the glucose carriers where separate signalling chains activate both steps [144]. We have used several insulin-like acting pharmacological tools to test which post-kinase signal transducers might be involved in the insulin signal from the receptor to the translocation step or the activation step. The effects of these pharmacological tools are shown in Figure 7. We have found that the insulin effect on glucose carrier translocation can be mimicked by phorbol esters $[99,102,103]$. As phorbol esters activate the protein kinase $C$ it is very likely that protein kinase $\mathrm{C}$ might be somehow involved in the signal between the receptor and the translocation process. Recently, we found that the phorbol ester effect is restricted to the translocation of GLUT-4 [102], not GLUT-1 suggesting a distinct translocation machinery for both carrier types [103]. We used other pharmacological tools to test which signal transducing elements could be involved in the second signal transmitting chain leading from the insulin receptor to carrier activation. As aluminium chloride [116], exogenously added phospholipase $\mathrm{C}$ [116] and a mixture of exogenously added inositolphosphooligosaccharides $[144,145]$ can all mimick the insulin 
Table 1. (See text)

Insulin receptor tyrosine kinase activity is modulated by:

Hyperinsulinaemia

Hypoinsulinaemia

Catecholamines, cAMP

Phorbol esters

Thyroid hormones

G-proteins

Lipids

Glycosylation

Adenosine

Hyperglycaemia

Polylysine

Inhibitory peptides

effect on carrier activity, it might be speculated that the carrier activating signal transmission involves a sequence of G-proteins, phospholipase C, and the release of inositol-phosphooligosaccharides.

\section{Location of defects in the insulin signalling chain: insulin receptor kinase defects as a possible cause of cellular insulin resistance}

The above-described mechanisms of insulin signal transduction can be used as a basis to discuss the molecular mechanisms leading to cellular insulin resistance. Cellular insulin resistance can be caused by defects at each level of the signal transmitting chain. At the level of the receptor kinase itself a number of 'defects' or 'inactive states' have been found in several model systems of insulin resistance, which provided the basis for later studies in insulin sensitive tissues of Type 2 diabetic patients.

\section{In vitro models and animal models}

The first cell model which showed an association between a reduced kinase activity and an insulin-resistant state was an insulin-resistant variant of a mouse melanoma cell line [146]. Even though no causal relationship could be proven between the reduced insulin receptor kinase activity in the insulin-resistant cells and the appearance of insulin resistance, this study gave a first hint that defects of the IRK might be involved in the pathogenesis of some forms of cellular insulin resistance. Important information came later from the study of IRK in skeletal muscle, liver and fat of rat and mouse models resembling some features of Type 2 diabetes in humans [147-150]. The obese diabetic Zucker rat is an animal model which has many features in common with an early phase of Type 2 diabetes in humans $[151,152]$. These animals are insulin resistant and clearly show elevated insulin levels. Insulin resistance of the target tissues of insulin action, especially skeletal muscle, has been demonstrated [152], and we found insulin insensitivity of the receptor kinase of skeletal muscle [147]. In contrast we could find no kinase defect in the livers of these animals, while Debant et al. [150] even reported a hyperresponsive kinase in adipose tissue in young animals. In another animal model, goldthioglucose-treated insulinresistant mice, LeMarchand et al. [148] have shown decreased IRK activity in skeletal muscle. The same group [153] also found a reduced kinase activity in skeletal muscle of genetically obese mice. We (unpublished observation) and others $[154,155]$ have not found this defect in $\mathrm{ob} / \mathrm{ob}$ mice, which suggests the possibility that it might be restricted to certain strains of these mice. Interestingly, reduced kinase activity has also been shown in insulinopoenic states. Kadowaki et al. [149] have shown decreased receptor autophosphorylation in the livers of streptozotocin-diabetic rats and Burant et al. [156] have shown structural and functional alterations of the kinase in skeletal muscle of the same animals. In summary, these data in animal models pointed towards a crucial role of skeletal muscle IRK in the pathogenesis of insulin resistance and prompted us to concentrate in later studies of Type 2 diabetic patients on the IRK of this tissue.

\section{The syndromes of severe insulin resistance in human subjects}

Important information has also come from the study of blood cells and fibroblasts from patients with the syndrome of severe type A insulin resistance [157-159]. Different phenotypes of insulin receptor defects exist in this syndrome with reduced insulin binding, normal insulin binding but reduced IRK, or a combination of both defects [159]. Recently insulin receptors from several patients were cloned and the amino acid exchanges leading to the different forms of receptor defects have been identified [160-165] which has substantially increased the understanding of structure and functional domains of the insulin receptor.

\section{In vitro induced insulin resistance: the IRK modulators (Table 1)}

The above-described models of cellular insulin resistance clearly demonstrate that IRK defects are associated with cellular insulin resistance and that IRK defects are an important pathophysiological mechanism leading to cellular insulin resistance. More detailed information about the mechanisms whereby the IRK can become inactive has been obtained from the study of cells where insulin resistance was induced in vitro. These studies have shown that the IRK-activity is under the control of modulator systems. Activation of inhibitory modulators might be an important mechanism causing insulin resistance through an inactive IRK. Some examples of these modulators shall be discussed in more detail. Catecholamines can induce an insulin resistance of the glucose transport system of isolated rat and human adipocytes in vitro $[85,87,166]$. We and others have shown that this insulin resistance correlated with an inhibition of the receptor kinase $[85,87,167$, 168].

In our study the insulin receptor isolated from these cells showed a more than $90 \%$ inhibition of the IRK measured in vitro [85], if a low ATP concentration was 
used in the in vitro phosphorylation assay. We found that a change of the affinity of the ATP binding site had occurred. Thus, it appears that catecholamine treatment can inhibit the insulin receptor tyrosine kinase through modulation of its ATP binding site. Recently a method to determine in vivo kinase activity has been used by Klein et al. [167] to show that the in vitro alteration described above correlates with a reduced kinase activity in the intact cell. It is speculated that this catecholamine-induced modulation of the receptor kinase occurs through serine phosphorylation of the insulin receptor $\beta$-subunit by the cyclic AMP dependent-kinase (cAMP-kinase). Phosphorylation of the $\beta$-subunit by the cAMP-kinase was at least shown in vitro by Roth et al. [169]. Tanti et al. [168] have also demonstrated an in vitro inhibition of the insulin receptor kinase by cAMP-kinase, but no phosphorylation was found. The site of phosphorylation has not yet been identified, although phosphorylation of the C-terminal tail is most likely (see below).

More important for the pathogenesis of insulin resistance than CAMP-dependent kinase might be protein kinase $\mathrm{C}$. Protein kinase $\mathrm{C}$-stimulating phorbol esters are able to induce in vitro insulin resistance of isolated adipocytes $[86,89]$ as well as FAO-hepatoma cells [88-90]. The IRK isolated from phorbol ester-treated cells showed reduced activity in vitro [86], and an altered affinity to ATP [86]. The mechanism which leads to the inhibition of the IRK is again likely to be serine phosphorylation of the insulin receptor. Thus, Jacobs et al. [88] and Takayama et al. $[89,90]$ reported that phorbol ester stimulation leads to a serine phosphorylation of the insulin $\beta$-subunit in the intact cell. Takayama et al. [90] have recently shown that this serine phosphorylation is due to activation of protein kinase $\mathrm{C}$, and that the inhibitory serine phosphorylation occurs at the C-terminal tail of the receptor [90]. The models of catecholamine and phorbol ester-induced insulin resistance showed that serine phosphorylation of the insulin receptor functions as an inhibitory mechanism. The mechanism might also be important in some other states of cellular insulin resistance. An important example is hyperglycaemia-induced insulin resistance.

Hyperglycaemia induces insulin resistance in isolated fat cells and this coincides with an inhibition of the IRK [171-173]. As simultaneously an increased protein kinase $C$ activity is found [171-175] it appears likely that hyperglycaemia-induced insulin resistance is associated with an IRK-inhibition through serine phosphorylation by protein kinase $\mathrm{C}$. This hypothesis is further supported by the observation that inhibitors of protein kinase $\mathrm{C}$ are able to suppress the inhibitory effect of glucose [173]. Another pathophysiologically important modulator is hyperinsulinaemia. The mechanism of IRK inhibition is, however, unclear [176] and it is not known whether insulin concentrations within the physiological range can induce an inhibition of the receptor kinase. A possible role of the membrane environment in inducing kinase resistance has recently been demonstrated in studies where the crucial role of phospholipids for kinase activity was shown $[170,177]$. It is tempting to speculate that alterations of membrane lipids might be a factor causing decreased kinase activity in disease states. Other in vitro factors regulating the kinase are adenosine [179] and polylysine, which activate the kinase in vitro against exogenous substrates [178]. There are also soluble inhibitor peptides, however, the physiological function remains unclear [181]. Thyroid hormones are also able to influence the IRK $[182,183]$. Furthermore, an inhibitory effect of gamma-S-GTP can be demonstrated in fat cell membranes suggesting a modulating function of a receptor associated G-protein [117]. It is interesting to speculate that altered expression or function of these G-proteins might be an important cause of cellular insulin resistance in disease states.

\section{IRK in insulin target tissues of Type 2 diabetic patients}

The studies described have shown that a kinase defect is apparently one possible cause of cellular insulin resistance. Furthermore, modulators causing an inactive state of the kinase in vitro have been described. On this basis we and others have investigated whether a kinase defect or an inhibitory modulation of the IRK plays a role in the pathogenesis of Type 2 diabetes. Several studies with tissue from Type 2 diabetic patients have now been conducted (Table 2). Freidenberg et al. [184] studied fat cells of Type 2 diabetic patients and were the first to find in vitro insulin insensitivity and unresponsiveness of the IRK isolated from cells of Type 2 diabetic patients. The authors concluded that in Type 2 diabetic patients a coupling defect between insulin binding and activation of the tyrosine kinase exists. The study does not provide information about the insulin receptor in intact fat cells. It was subsequently shown that this kinase defect is partially reversed after weight loss in these patients [185]. As a mechanism of the kinase defect an altered proportion of active and inactive receptors was proposed [185]. Caro et al. [186] found a similar defect in liver. Skeletal muscle, probably the most important tissue in the pathogenesis of Type 2 diabetic patients was also studied by Caro et al. [187], Arner et al. [188] and by ourselves [147, 189].

We and Arner have found a kinase defect or inactivity in the skeletal muscle of Type 2 diabetic patients as described below. Contrary to this Caro et al. [186] have found no Type 2 diabetes-specific kinase defect. More recently a reduced IRK-activity was also described in the skeletal muscle of Type 2 diabetic Pima Indians [198]. Possible reasons for these discrepant findings are discussed elsewhere in detail [12]. Briefly, it is possible that the different localisation of the skeletal muscle, i. e. different fibre composition, is important. Another possible explanation might be provided by the different patient characteristics, i.e. body mass index and insulin levels. Our results comparing IRK from non-obese Type 2 diabetic patients and non-obese control subjects, isolated as described earlier [190], may be summarized as follows. No difference in insulin binding was found. However, a shift of the insulin dose response curve to the right was apparent, and there was a significant reduction of the maximal activity of $40-50 \%$ in autophosphorylation and of 50$60 \%$ in GLUT-4:Tyr1 substrate phosphorylation. These results are in good agreement with the results of Arner et 
Table 2. Insulin receptor characteristics in obesity and Type 2 (non-insulin-dependent) diabetes compared with non-obese control subjects

\begin{tabular}{|c|c|c|c|c|c|c|}
\hline Tissue & Type of patient & Insulin levels & Insulin binding & $\begin{array}{l}\text { Auto- } \\
\text { phosphorylation }\end{array}$ & $\begin{array}{l}\text { Substrate } \\
\text { phosphorylation }\end{array}$ & Authors \\
\hline Fat: & $\begin{array}{l}\text { normal obese } \\
\text { Type } 2 \text { diabetic obese }\end{array}$ & $\uparrow$ & $\begin{array}{l}\downarrow 50 \% \\
\downarrow 60 \%\end{array}$ & $\vec{\downarrow} 50 \%$ & $\overrightarrow{30-50 \%}$ & Freidenberg [184] \\
\hline & $\begin{array}{l}\text { Normal obese } \\
\text { Type } 2 \text { diabetic obese } \\
\text { Type } 2 \text { diabetic nonobese }\end{array}$ & $\begin{array}{l}\uparrow \\
\uparrow \\
\uparrow\end{array}$ & $\begin{array}{l}\rightarrow \\
\rightarrow\end{array}$ & $\begin{array}{l}\text { ND } \\
\text { ND }\end{array}$ & $\begin{array}{l}\downarrow 50 \% \\
\downarrow 50 \% \\
\downarrow 50 \%\end{array}$ & Arner [188] \\
\hline & $\begin{array}{l}\text { Type } 2 \text { diabetic nonobese } \\
\text { Type } 2 \text { diabetic obese } \\
\text { (Pima Indian) }\end{array}$ & $\uparrow$ & $\begin{array}{l}\rightarrow \\
\rightarrow\end{array}$ & $\downarrow 40-50 \%$ & $\underset{\downarrow}{\downarrow} \downarrow$ & $\begin{array}{l}\text { Present author }[147,189] \\
\text { Bulangu [198] }\end{array}$ \\
\hline
\end{tabular}

Note: ND, not determined; $\uparrow$, increased; $\downarrow$, decreased; $\rightarrow$, unchanged

al. [188] concerning the receptor kinase from non-obese control subjects and non-obese Type 2 diabetic patients. The conclusion from our own study and that of Arner et al. [188] was that the receptor kinase of skeletal muscle is defective in Type 2 diabetic patients. Considering these data it is important to note that Arner et al. [188] have shown that obesity itself already decreases kinase activity. It is thus possible that in extremely obese patients the kinase is already depressed to an extent which makes it impossible to detect an additional effect in Type 2 diabetic patients. While the depressed IRK of fat cells is partially reversible after weight loss, it is interesting to note that the decreased IRK of skeletal muscle is found independently of the weight and the metabolic situation of the patients. Therefore, it seems possible that a reduced kinase activity of the skeletal muscle might be a "primary defect" found in a population at high risk of developing obesity or Type 2 diabetes while the IRK inactivity found in other tissues might be merely a secondary event due to modulator effects, for instance hyperglycaemia-induced serine phosphorylation by protein kinase $\mathrm{C}$ or another secondary modulation event.

What is the molecular mechanism causing the reduced kinase activity of the skeletal muscle in non-obese Type 2 diabetic patients? There is no conclusive answer to this question at present. However, our studies of skeletal muscle IRK including the tryptic peptide mapping of the phosphorylated $\beta$-subunit suggest the possibility that the recently proposed autoactivation cascade of the IRK [41] might be disturbed in diabetic patients [189]. The diabetic kinase obviously does not proceed to the fully active triphosphorylated form, as in the case of the kinase from non-diabetic control subjects [189]. If this observation is combined with the recent findings in adipose tissue from Type 2 diabetic patients [185], it might be speculated that the proportion of receptors converting to the triphosphorylated form is reduced in Type 2 diabetic patients.

Further studies will have to answer the questions as to whether the reduced kinase activities, which were found in vitro, are also relevant in the intact cell.

\section{What is the contribution of an IRK defect to the pathogenesis of Type 2 diabetic patients}

A reduced IRK activity was found in the target tissues of insulin action in Type 2 diabetic patients [184-185]. It is likely that this kinase inactivity is a pathophysiologically relevant factor in the development of the insulin resistance. Other defects might be located at the point of signalling to glycogen synthetase and in the glucose carrier system. However, it is not clear whether IRK inactivity reflects a primary defect or represents a secondary event in the development of this disease. It is clear that genetic factors contribute to the predisposition to the development of Type 2 diabetes and it has been demonstrated, that insulin resistance of the major target tissues of insulin action plays an important role in the pathogenesis of this disease. One of the multiple candidate genes possibly involved in the pathogenesis of Type 2 diabetes might be the gene for the insulin receptor. However, all of the above-mentioned structural defects of the receptor [157-165] caused extreme insulin resistance. On the other hand it is interesting that some patients with extreme insulin resistance have relatives in whom the heterozygosity for the mutated receptor gene is associated with moderate insulin resistance similar to that found in Type 2 diabetic patients [191]. Even though these are interesting data there is at present no proof from genetic studies that genomic polymorphisms of the insulin receptor gene are significantly associated with Type 2 diabetic patients [192, 193]. We investigated exon 20 of the receptor gene from Type 2 diabetic patients with severe alterations of the autophosphorylation cascade and found no mutation [194]. Other groups could not demonstrate genetic defects of the insulin receptor in diabetic Pima Indians [195] but could show an increased risk for gestational diabetes mellitus associated with insulin receptor and insulin-like growth factor-II restriction fragment length polymorphisms [196].

In summary, there is no strong evidence for a primary inactivity of the IRK due to a sequence abnormality of the receptor protein itself. If it is still assumed, for the reasons discussed above, that skeletal muscle IRK inactivity be- 
longs to early events in the pathogenesis of the disease a primary "modulator abnormality" might be a more likely explanation. Furthermore, we recently observed that the expression of the receptor isoforms HIR-A and HIR-B is altered in the skeletal muscle of Type 2 diabetic patients [197]. Further studies are now required to evaluate whether this phenomenon is a primary event related to the development of insulin resistance or whether this alteration compensates for a defect at another level of the insulin signalling chain.

Acknowledgements. I wish to thank my colleagues and co-workers in Munich for their continuous support in recent years. In particular I wish to thank my close collaborators Drs. B.Obermaier-Kusser, J.Mushack, E.Seffer, B.Ermel, Ch.Mühlbacher, F.Machicao, M. Kellerer and B. Vogt for all their contributions to the work presented here. I wish to also thank Drs. C. R. Kahn and M. F. Withe in Boston, E. Karnieli in Haifa, E. VanObberghen in Nice and A. Ullrich in Martinsried for their continuous help and collaboration. My thanks also go to Professor H. Mehnert, who provided the environment which allowed me to do basic research and clinical work side by side.

\section{References}

1. Reaven GM, Bernstein R, Davis B, Olefsky JM (1976) Nonketotic diabetes mellitus: insulin deficiency or insulin resistance? Am J Med 60: 80-88

2. De Fronzo RA (1988) The triumvirate: $\beta$-cell, muscle, liver. A collusion responsible for NIDDM. Diabetes 37:667-687

3. Reaven GM (1983) Insulin resistance in noninsulin-dependent diabetes mellitus. Does it exist and can it be measured? Am J Med 74:3-17

4. Olefsky JM, Ciaraldi TP, Kolterman OG (1985) Mechanism of insulin resistance in non-insulin-dependent (type II) diabetes. Am J Med 79: 12-22

5. Olefsky JM (1981) Insulin resistance and insulin action. An in vitro and in vivo perspective. Diabetes 30: 148-162

6. Eriksson J, Franssila-Kallunki A, Ekstrand A et al. (1989) Early metabolic defects in persons at increased risk for non-insulindependent diabetes melllitus. N Engl J Med 321:337-343

7. Warram JH, Martin BH, Krolewski AS, Soeldner JS, Kahn CR (1990) Slow removal rate and hyperinsulinaemia precede the development of type II diabetes in the offspring of diabetic patients. Ann Intern Med 113:909-1015

8. Freychet P, Kahn CR, Jarrett DB, Roth J (1971) Insulin receptors in the liver: specific binding of ${ }^{125}$ I-insulin to the plasma membrane and its relations to insulin bioactivity. Proc Natl Acad Sci 68: 1833-1837

9. Cuatrecasas P (1971) Insulin receptor interactions in adipose tissue cells: direct measurement and properties. Proc Natl Acad Sci 68: 1264-1268

10. Kono T, Barham FW (1971) The relationship between the insulin-binding capacity of fat cells and the cellular response to insulin. J Biol Chem 246: 6210-6216

11. Kasuga M, Karlsson FA, Kahn CR (1982) Insulin stimulates the phosphorylation of the 95.000 Dalton subunit of its own receptor. Science $215: 185-187$

12. Häring HU, Obermaier-Kusser B (1990) The insulin receptor: its role in insulin action and in the pathogenesis of insulin resistance. Diabetes Ann 5:537-567

13. Kasuga M, Zick Y, Blithe DL, Karlsson FA, Häring HU, Kahn CR (1982) Insulin stimulation of phosphorylation of the $\beta$-subunit of the insulin receptor. J Biol Chem 257: 9891-9894

14. Häring HU, Kasuga M, Kahn CR (1982) Insulin receptor phosphorylation in intact adipocytes and in a cell-free system. Biochem Biophys Res Commun 108: 1538-1545
15. VanObberghen E, Kowalski A (1982) Phosphorylation of the hepatic insulin receptor. FEBS Lett 143: 179-192

16. Häring HU, Kasuga M, White MF, Crettaz M, Kahn CR (1984) Phosphorylation and dephosphorylation of the insulin receptor: evidence against an intrinsic phosphatase activity. Biochemistry 23: 3298-3306

17. Kasuga M, Fujita-Yamaguchi Y, Blithe DL, Kahn CR (1985) Tyrosine-specific protein kinase activity is associated with the purified insulin receptor. Proc Natl Acad Sci USA 80: 2137-2141

18. VanObberghen E, Rossi B, Kowalski A, Gazzano H, Ponzio G (1983) Receptor-mediated phosphorylation of the hepatic insulin receptor, evidence that the $M=95.000$ receptor subunit is its own kinase. Proc Natl Acad Sci USA 80: 945-949

19. Shia MA, Pilch PF (1983) The $\beta$-subunit of the insulin receptor is an insulin-activated protein kinase. Biochemistry $22: 717-721$

20. Ullrich A, Bell JR, Chen EY et al. (1985) Human insulin receptor and its relationship to the tyrosine kinase family of oncogenes. Nature 313: 756-761

21. Ebina Y, Ellis L, Jarragin K et al. (1985) The human insulin receptor c-DNA: the structural basis for hormone-activated transmembrane signalling. Cell 40: 747-758

22. Seino S, Seino M, Nishi S, Bell GI (1989) Structure of the human insulin receptor gene and characterization of its promoter. Proc Natl Acad Sci USA 86: 114-118

23. Moller DE, Yokota A, Caro JF, Flier JS (1989) Tissue-specific expression of two alternatively spliced insulin receptor mRNAs in man. Mol Endocrinol 3: 1263-1269

24. Mosthaf L, Grako K, Dull TJ, Coussens L, Ullrich A, McClain DA (1990) Functionally distinct insulin receptors generated by tissue-specific alternative splicing. EMBO J 9:2409-2414

25. Hedo JA, Kasuga M, VanObberghen E, Roth J, Kahn CR (1981) Direct demonstration of glycosylation of insulin receptor subunits by biosynthetic and external labelling: evidence for heterogeneity. Proc Natl Acad Sci USA 78: 4791-4795

26. DeMeyts P, Gu JL, Shymko RM, Bell G, Whittaker J (1988) Identification of an insulin receptor binding domain complementary to the cooperative site of insulin. Diabetologia 31: 484 (Abstract)

27. DeMeyts P, Gu JL, Katuria S, Shymko RM, Kaplan B, Smal J (1989) Insulinomimetic properties of a synthetic insulin receptor $\alpha$-subunit binding domain. Diabetes 38 [Suppl 2]: 1 (Abstract)

28. Yip CC, Hsu H, Patel RG, Hawley DM, Maddux A, Goldfine ID (1988) Localization of the insulin-binding site to the cysteine-rich region of the insulin receptor $\alpha$-subunit. Biochem Biophys Res Commun 157: 321-329

29. Rafaeloff R, Patel RG, Yip CC, Hawley DM (1989) Effects of site-specific mutations of the insulin-binding site in the cysteinrich domain of the insulin receptor $\alpha$-subunit. Diabetes 38 [Suppl 2]: 1 (Abstract)

30. Matsushime H, Wang L, Shibuya M (1986) Human c-ros-1 gene homologeous to the v-ros sequence of UR2 sarcoma virus encodes for a transmembrane receptor-like molecule. Mol Cell Biol 6:3000-3004

31. Anderson SK, Gibbs CP, Tanaka A, Kung H (1985) Human cellular src gene: nucleotide sequence and derived amino acid sequence of the region coding for the carboxy-terminal two-thirds of pp60 c-src. Mol Cell Biol 5: 1122-1129

32. Semba K, Kamata N, Toyoshima K, Yamamoto T (1985) A $\mathrm{v}$-erbB-related protooncogene, c-erbB-2, is distinct from the c-erbB-1/epidermal growth factor-receptor gene and is amplified in a human salivary gland adenocarcinoma. Proc Natl Acad Sci USA 82: 6497-6501

33. White MF, Häring HU, Kasuga M, Kahn CR (1984) Kinetic properties and sites of autophosphorylation of the partially purified insulin receptor from hepatoma cells. J Biol Chem 259: 255-264

34. White MF, Takayama S, Kahn CR (1985) Differences in the sites of phosphorylation of the insulin receptor in vivo and in vitro. J Biol Chem 260: 9470-9478 
35. Tornqvist HE, Pierce MW, Frackelton AR (1987) Identification of insulin receptor tyrosine residues autophosphorylated in vitro. J Biol Chem 262: 10212-10219

36. Tornquist HE, Cunsalus JR, Nemenoff RA, Frackelton AR, Pierce MW, Avruch J (1988) Identification of the insulin receptor tyrosine residues undergoing insulin-stimulated phosphorylation in intact rat hepatoma cells. J Biol Chem 263: 350-359

37. Tornqvist HE, Avruch J (1988) Relationship of site-specific $\beta$ subunit tyrosine autophosphorylation to insulin activation of the insulin receptor (tyrosine) protein kinase activity. J Biol Chem 263: 4593-4601

38. Tavare JM, Denton RM (1988) Studies on the autophosphorylation of the insulin receptor from human placenta. Analysis of the' sites phosphorylated by two-dimensional peptide mapping. Biochem J 252: 607-615

39. Tavare JM, O'Brien RM, Siddle K, Denton RM(1988) Analysis of insulin-receptor phosphorylation sites in intact cells by twodimensional phosphopeptide mapping. Biochem J 253; 783-788

40. White MF, Livingston JN, Backer JM et al. (1988) Mutation of the insulin receptor at tyrosine 960 inhibits signal transmission but does not affect its tyrosine kinase activity. Cell 45: 641-649

41. White MF, Shoelson SE, Keutmann H, Kahn R (1988) A cascade of tyrosine autophosphorylation in the $\beta$-subunit activates the phosphotransferase of the insulin receptor. J Biol Chem 263: 2969-2980

42. Ellis L, Clauser E, Morgan DO, Edery M, Roth A, Rutter WJ (1986) Replacement of insulin receptor residues 1162 and 1163 compromises insulin stimulated kinase activity and uptake of 2-deoxy glucose. Cell 45: 721-732

43. Debant A, Clauser E, Ponzio G et al. (1988) Replacement of insulin receptor tyrosine residues 1162 and 1163 does not alter the mitogenic effect of the hormone. Proc Natl Acad Sci USA 85: 8032-8036

44. Ebina Y, Araki E, Taira M et al. (1987) Replacement of lysine residue 1030 in the putative ATP-binding region of the insulin receptor abolishes insulin- and antibody-stimulated glucose uptake and receptor kinase activity. Proc Natl Acad Sci USA 84: 704-708

45. Goren HJ, White MF, Kahn CR (1987) Separate domains of the insulin receptor contain sites of autophosphorylation and tyrosine kinase activity. Biochemistry 26: 2374-2382

46. Herrera R, Lebwohl D, Garcia de Herreros A, Kallen RG, Rosen OM (1988) Synthesis, purification, and characterization of the cytoplasmic domain of the human insulin receptor using a baculovirus expression system. J Biol Chem 263: 5560-5568

47. Maegawa H, McClain DA, Freidenberg G et al. (1988) Properties of a human insulin receptor with a $\mathrm{COOH}$-terminal truncation, II. Truncated receptors have normal kinase activity but are defective in signaling metabolic effects. J Biol Chem 263: $8912-8917$

48. McClain DA, Maegawa H, Levy J et al. (1988) Properties of a human insulin receptor with a $\mathrm{COOH}$-terminal truncation. Insulin binding, autophosphorylation, and endocytosis. J Biol Chem 263: 8904-8911

49. Lewis RE, Perregaux DG, Perregaux SB (1989) Insulin-stimulated serine/threonine phosphorylation of insulin receptor in vitro is due to enhanced catalytic activity of an associated serine kinase (IRSK). Diabetes 38 [Suppl 2]: 1 (Abstract)

50. Lewis RE, Perrigaux S, Perrigaux D, Whittaker J, Czech MP (1990) Insulin receptor regulation by serine/threonine phosphorylation: analysis of receptor threonine 1336 mutant in a transient expression system. In: Bonora E, Cigolini M, Moghetti P, Zoppini G (eds) IV International symposium on insulin receptor and insulin action. Molecular and clinical aspects, pp $119-120$

51. Backer JM, Ullrich A, Kahn CR, White MF (1990) Receptormediated internalization of insulin requires a 12 amino acid sequence in the juxtamembrane region of the receptor $\beta$-subunit. In: Bonora E, Cigolini M, Moghetti P, Zoppini G (eds) IV International symposium on insulin receptor and insulin action. Molecular and clinical aspects, pp 14-15
52. Chen WJ, Goldstein JL, Broom MS (1990) NPX, a sequence often found in cytoplasmic tails, is required for coated pit mediated internalization of the low density lipoprotein receptor. $\mathrm{J}$ Biol Chem 265:3116-3123

53. Kellerer M, Ermel B, Vogt B, Obermaier-Kusser B, Ullrich A, Häring HU (1990) Different $\alpha$-subunit structure of type A and $B$ human insulin receptor determines different tyrosine kinase activities. Diabetologia 33 [Suppl]: 35 (Abstract)

54. Vogt B, Carrascosa JM, Ermel B, Ullrich A, Häring HU (1991) The two isotypes of the human insulin receptor (HIR-A and HIR-B) follow different internalization kinetics. Biochem Biophys Res Commun 177: 1013-1088

55. Johnson JD, Wong ML, Rutter WJ (1988) Properties of the insulin-receptor ectodomain. Proc Natl Acad Sci USA 85: 7516-7520

56. Sweet LJ, Morrison BD, Wilden PA, Pessin JE (1987) Insulindependent intermolecular subunit communication between isolated $\alpha-\beta$ heterodimeric insulin receptor complexes. J Biol Chem 262: 16730-16738

57. O'Hare T, Pilch PF (1988) Separation and characterization of three insulin receptor species that differ in subunit composition. Biochemistry 27: 5693-5700

58. Kahn CR (1985) The molecular mechanism of insulin action. Ann Rev Med 36: 429-451

59. Debant A, Ponzio G, Clauser E, Contreres JO, Rossi B (1989) Receptor crosslinking restores an insulin metabolic effect altered by mutation on tyrosine 1162 and tyrosine 1163 . Biochemistry 28: 14-17

60. Frias I, Waugh SM (1989) Probing the $\alpha-\alpha$ subunit interface region in the insulin receptor, location of interhalf disulfide(s). Diabetes 38 [Suppl 2]: 60 (Abstract)

61. Shoelson SE, White MF, Kahn CR (1988) Tryptic activation of the insulin receptor. Proteolytic truncation of the $\alpha$-subunit releases the $\beta$-subunit from inhibitory control. J Biol Chem 263 : $4852-4860$

62. Prigent SA, Ganderton RH, Soos MA, Stanley KK, Siddle K (1990) Site-specific antibodies as probes of insulin receptor: structure and function. In: Bonora $\mathrm{E}$, Cigolini $\mathrm{M}$, Moghetti $\mathrm{P}$, Zoppini G (eds) IV International symposium on insulin receptor and insulin action. Molecular and clinical aspects, pp 166167

63. Gherzi R, Sesti G, Andraghetti G et al. (1989) An extracellular domain of the insulin receptor $\beta$-subunit with regulatory function on protein-tyrosine kinase. J Biol Chem 264:8627-8635

64. Maddux BA, Goldfine ID (1990) Evidence that insulin plus ATP can induce a conformational change in the $\beta$-subunit of the insulin receptor without inducing receptor autophosphorylation. In: Bonora E, Cigolini M, Moghetti P, Zoppini G (eds) IV International symposium on insulin receptor and insulin action. Molecular and clinical aspects.

65. Baron V, Gautier N, Hainaut P, Scimeca JC, Dolais-Kitabgi J, VanObberghen $E$ (1990) Insulin binding to its receptor induces a conformational change in the receptor $\mathrm{C}$-terminus. In: Bonora E, Cigolini M, Moghetti P, Zoppini G (eds) IV International symposium on insulin receptor and insulin action. Molecular and clinical aspects, pp 20-21

66. Kellerer M, Ermel B, Vogt B, Ullrich A, Häring HU (1990) Different $\alpha$-subunit structures of the human insulin receptors type $A$ and $B$ affect the tyrosine kinase activity of the $\beta$-subunit. In: Bonora E, Cigolini M, Moghetti P, Zoppini G (eds) IV International symposium on insulin receptor and insulin action. Molecular and clinical aspects, $\mathrm{p} 103$

67. Accili D, Kadowaki T, Mosthaf L, Ullrich A, Taylor SI (1990) Molecular basis of insulin resistance in patients with genetic forms of extreme insulin resistance. In: Bonora $\mathrm{E}$, Cigolini M, Moghetti P, Zoppini G (eds) IV International symposium on insulin receptor and insulin action. Molecular and clinical aspects, pp 5-6

68. Ballotti R, Baron V, Gautier N et al. (1990) Activation and regulation of the insulin receptor kinase. Hormones and cell regulation. Colloque Inserm 210:29-36 
69. White MF, Maron R, Kahn CR (1985) Insulin rapidly stimulates tyrosine phosphorylation of a 185.000 molecular weight protein in intact cells. Nature 163: 76-80

70. Häring HU, White MF, Machicao F, Ermel B, Schleicher E, Obermaier B (1987) Insulin rapidly stimulates phosphorylation of a $46 \mathrm{kD}$ a membrane protein on tyrosine residues as well as a phosphorylation of several soluble proteins in intact fat cells. Proc Natl Acd Sci USA 84: 113-117

71. Machicao F, Häring $H$, White MF, Carrascosa JM, Obermaier $\mathrm{B}$, Wieland $\mathrm{OH}(1987) \mathrm{A} 180,000$ molecular weight protein is an endogenous substrate for the insulin receptor associated tyrosine kinase in human placenta. Biochem J 243: 797-801

72. Rees-Jones R, Taylor S (1985) An endogenous substrate for the insulin receptor-associated tyrosine kinase. J Biol Chem 260 : 4461-4467

73. Sedoul JC, Pegron JF, Ballotti R, Debant A, Fehlmann M, VanObberghen E (1985) Identification of a cellular 110.000 Da protein substrate for the insulin-receptor kinase. Biochem. $\mathbf{J}$ 227: 887-892

74. Momomura K, Topa K, Seyama Y, Takaku F, Kasuga M (1988) Insulin induced tyrosine-phosphorylation in intact rat adipocytes. Biochem Biophys Res Commun 155: 1181-1186

75. Margolis RN, Taylor SI, Seminara D, Hubbard AL (1988) Identification of pp120, an endogenous substrate for hepatocyte insulin receptor tyrosine kinase, as an integral membrane glycoprotein of the bile canalicular domain. Proc Natl Acad Sci USA 85: 7256-7259

76. Bernier M, Laird DM, Lane DM (1987) Insulin activated tyrosine phosphorylation of a 15 kilodalton protein in intact 3T3-L1 adipocytes. Proc Natl Acad Sci USA 84: 1844-1848

77. Hoffmann RD, Flores-Riveros JR, Liao K, Laird DM, Lane MD (1988) Identification of phosphorylated 422(aP2) protein as pp15, the 15-kilodalton target of the insulin receptor tyrosine kinase in 3T3-L1 adipocytes. Proc Natl Acad Sci USA 85: $8835-8839$

78. Izumi T, White MF, Kadowaki T, Takaku F, Akanuma Y, Kasuga M (1987) Insulin-like growth factor I rapidly stimulates tyrosine phosphorylation of a $\mathrm{Mr} 185.000$ protein in intact cells. J Biol Chem 262: 1282-1287

79. Madoff DH, Martensen TM, Lane DM (1988) Insulin and insulin-like growth factor I stimulate the phosphorylation on tyrosine of a $160 \mathrm{kDa}$ cytosolic protein in 3T3-L1 adipocytes. Biochem J 252: 7-15

80. Obermaier-Kusser B, Ermel B, Mühlbacher C, Häring HU (1988) $\mathrm{A} \mathrm{M}_{\mathrm{r}} 60 \mathrm{kDa}$ serine kinase: substrate of the insulin receptor kinase in vitro and in the intact cell. Diabetes Res Clin Pract 60 [Suppl 1]: 67-93

81. Häring HU, White MF, Kahn CR, Ahmad Z, DePaoli-Roach AA, Roach PJ (1985) Interaction of the insulin receptor kinase with serine/threonine kinases in vitro. J Cell Biochem 28 : $171-182$

82. Laurino JP, Colca JR, Pearson JD, De Wald DB, McDonald JM (1988) The in vitro phosphorylation of calmodulin by the insulin receptor tyrosine kinase. Arch Biochem Biophys 265: 8-21

83. Nong ECC, Eacks DB, Laurino JF, McDonald JM (1988) Characteristics of calmodulin phosphorylation by the insulin receptor kinase. Endocrinology 123: 1830-1836

84. Rothenberg PL, Lane WS, Karasik A, Backer J, White MF, Kahn CR (1991) Purification and partial sequence analysis of pp185, the major cellular substrate of the insulin receptor tyrosine kinase. J Biol Chem 266: 8302-8311

85. Häring HU, Kirsch D, Obermaier B, Ermel B, Machicao F (1986) Decreased tyrosine kinase activity of insulin receptor isolated from rat adipocytes rendered insulin-resistant by catecholamine treatment in vitro. Biochem $\mathrm{J} 234: 59-66$

86. Häring HU, Kirsch D, Obermaier B, Ermel B, Machicao F (1986) Tumor promoting phorbolesters increase the $\mathrm{Km}$ of the ATP-binding site of the insulin receptor kinase from rat adipocytes. J Biol Chem 261: 3869-3875

87. Obermaier B, Ermel B, Kirsch D et al. (1987) Catecholamines and tumour promoting phorbolesters inhibit insulin receptor kinase and induce insulin resistance in isolated human adipocytes. Diabetologia 30: 93-99

88. Jacobs S, Sahyoun NE, Saltiel AR, Cuatrecasas P (1983) Phorbol esters stimulate the phosphorylation of receptors for insulin and somatomedin. Proc Natl Acad Sci USA 80: 6211-6213

89. Takayama S, White MF, Lauris V, Kahn CR (1984) Phorbol ester modulate insulin receptor phosphorylation and insulin action in cultured hepatoma cells. Proc Nat Acad Sci USA 81: $7797-7801$

90. Takayama S, White MF, Kahn CR (1988) Phorbol ester induced serine phosphorylation of the insulin receptor decreases its tyrosine kinase activity. J Biol Chem 263: 3340-3447

91. Kellerer M, Seffer E, Mushack J, Obermaier-Kusser B, Häring HU (1990) TPA inhibits insulin stimulated PIP hydrolysis in fat cell membranes: evidence for modulation of insulin dependent phospholipase $\mathrm{C}$ by proteinkinase $\mathrm{C}$. Biochem Biophys Res Commun 172: $446-454$

92. Lewis RE, Perregaux DG, Perregaux SB (1989) Insulin stimulated serine/threonine phosphorylation of insulin receptor in vitro is due to enhanced catalytic activity of an associated serine kinase (IRSK). Diabetes 38: [Suppl 2]: 1 (Abstract)

93. Ray BL, Sturgill TW (1988) Insulin stimulated microtubuleassociated protein kinase is phosphorylated on tyrosine and threonine in vivo. Proc Natl Acad Sci USA 85: 3753-3757

94. Gazzano H, Kowalski A, Fehlmann M, VanObberghen E (1988) Two different protein kinase activities are associated with the insulin receptor. Biochem J 216: 575-582

95. Yu KT, Khalaf N, Czech MP (1987) Insulin stimulates a membrane-bound serine kinase that may be phosphorylated on tyrosine. Proc Natl Acad Sci USA 84: 3972-3976

96. Smith DM, King MJ, Sale GJ (1988) Two systems in vitro that show insulin-stimulated serine kinase activity toward the insulin receptor. Biochem J 250:509-519

97. Klarlund JK, Bradford AP, Yu K et al. (1990) Intracellular signalling by the insulin receptor: characterization of a novel kemptide, insulin-sensitive, protein kinase (KIK) In: Bonora $E$, Cigolini M, Moghetti P, Zoppini G (eds) IV International symposium on insulin receptor and insulin action. Molecular and clinical aspects, pp 107-108

98. Kirsch D, Obermaier B, Häring HU (1985) Phorbolesters enhance basal D-glucose transport but inhibit insulin stimulation of D-glucose transport and insulin binding in isolated rat adipocytes. Biochem Biophys Res Commun 128: 824-832

99. Mühlbacher C, Karnieli E, Schaff P et al. (1988) Phorbol esters imitate in rat fat-cells the full effect of insulin on glucose-carrier translocation, but not on 3-O-methyl-glucose transport activity. Biochem J 249: 865-870

100. Farese RV, Vila M, Hoffmann J et al. (1990) Phospholipid signalling systems in insulin action. In: Bonora $\mathbf{E}$, Cigolini $\mathrm{M}, \mathrm{Mo}-$ ghetti P, Zoppini G (eds) IV International symposium on insulin receptor and insulin action. Molecular and clinical aspects, pp $72-73$

101. Cooper DR, Ishizuka T, Dao ML, Watson JE, Standaert ML, Farese RV (1990) Regulation of protein kinase C by insulin and diacylglycerol. In: Bonora E, Cigolini M, Moghetti P, Zoppini G (eds) IV International symposium on insulin receptor and insulin action. Molecular and clinical aspects, $p 52$

102. Vogt B, Mushack J, Seffer E, Häring HU (1990) The phorbol ester TPA induces a translocation of the insulin sensitive glucose carrier (GLUT4) in fat cells. Biochem Biophys Res Commun 168: 1089-1094

103. Vogt B, Mushack J, Seffer E, Häring HU (1991) The translocation of the glucose transporter subtypes GLUT1 and GLUT4 in isolated fat cells is differently regulated by phorbol esters. Biochem J 275: 597-600

104. Machicao F, Wieland OH (1984) Evidence that the insulin receptor-associated protein kinase acts as phosphatidylinositol kinase. FEBS Lett 175: 113 116

105. Sale J, Fujita-Yamaguchi Y, Kahn CR (1986) Characterization of phosphatidyl kinase activity associated with the insulin receptor. Eur J Biochem 155: 345-351 
106. Carrascosa J, Schleicher E, Maier R, Hackenberg C, Wieland $\mathrm{OH}$ (1988) Separation of the protein-tyrosine kinase and phosphatidylinositol kinase activities of the human placental insulin receptor. Biochem Biophys Acta Ser Mol Cell Res 971: 170-178

107. Backer JM, Ullrich A, Kahn CR, White MF (1990) Receptormediated internalization of insulin requires a 12 amino acid sequence in the juxtamembrane region of the insulin receptor $\beta$ subunit. In: Bonora E, Cigolini M, Moghetti P, Zoppini G (eds) IV International symposium on insulin receptor and insulin action. Molecular and clinical aspects, pp 14-15

108. Carrascosa JM, Vogt B, Ullrich A, Häring HU (1991) Activation of phosphatidylinosttol-3 kinase by insulin is mediated by both $\mathrm{A}$ and $\mathrm{B}$ human insulin receptor. Biochem Biophys Res Commun 174: 123-127

109. Heyworth CM, Houslay MD (1983) Insulin exerts actions through a distinct species of guanine nucleotide regulatory protein: inhibition of adenylate cyclase. Biochem J 214: 547-552

110. Heyworth CM, Whetton AD, Wong S, Martin BR, Houslay MD (1985) Insulin inhibits the cholera-toxin-catalysed ribosylation of a $\mathrm{Mr} 25000$ protein in rat liver plasma membranes. Biochem J 228: 593-603

111. Rothenberg PL, Kahn CR (1988) Insulin inhibits pertussis toxin-catalyzed ADP-ribosylation of G-proteins. Evidence for a novel interaction between insulin receptors and G-proteins. J Biol Chem 263: 15546-15552

112. Gawler D, Milligan G, Spiegel AM, Unson LG, Houslay MD (1987) Abolition of the expression of inhibitory guanine nucleotide regulatory protein G1 activity in diabetes. Nature 327 : 229-232

113. O'Brian RM, Houslay MD, Milligan G, Siddle K (1987) The insulin receptor tyrosyl kinase phosphorylates holomeric forms of the guanine nucleotide regulatory proteins $G_{i}$ and $G_{0}$. FEBS Lett 212: 281-288

114. Krupinski J, Rajaram R, Lakonishok M, Benovic JL, Cerione RA (1988) Insulin-dependent phosphorylation of GTP-binding proteins in phospholipid vesicles. J Biol Chem 263: 12333-12341

115. Zick Y, Sagi-Eisenberg R, Pines M, Gierschik P, Spiegel AM (1986) Multisite phosphorylation of the $\alpha$-subunit of transducin by the insulin receptor kinase and protein kinase C. Proc Natl Acad Sci USA 83: 9294-9297

116. Obermaier-Kusser B, Mühlbacher C, Mushack J, Rattenhuber E, Fehtmann M, Häring HU (1988) Regulation of glucose carrier activity by $\mathrm{AlCl}_{3}$ and phospholipase $\mathrm{C}$ in fat cells. Biochem J 256: 515-520

117. Kellerer M, Obermaier-Kusser B, Pröfrock A et al. (1991) Insulin activates GTP-binding to a 40,000 Dalton protein in fat cells. Biochem J 276: 103-108

118. Jo H, Davis HW, McDonald JM (1990) Identification of a GTPbinding protein associated with the insulin receptor. Diabetes 39 [Suppl 1]:1 (Abstract)

119. Fox JA, Soliz NM, Saltiel AR (1987) Purification of a phosphatidylinositol-glycan-specific phospholipase C from liver plasma membranes. Proc Natl Acad Sci USA 84: 2663-2667

120. Koepfer-Hobelsberger B, Wieland OH (1984) Insulin activates phospholipase $\mathrm{C}$ in fat cells: similarity with the activation of pyruvate dehydrogenase. Mol Cell Endocrin 36: 123-129

121. Egan JJ, Saltis J, Wek SA, Simpson IA, Londos C (1990) Insulin, oxytocin, and vasopressin stimulate protein kinase $\mathrm{C}$ activity in adipocyte plasma membranes. Proc Natl Acad Sci USA 87: 1052-1056

122. Yoshimoto A, Nakanishi K, Anzai T, Komine S (1990) The activation of phosphatidylinositol-specific phospholipase $C$ by insulin in mammary epithelial cells of lactating mouse. Cell Biochem Funct 8: 163-166

123. Cooper DR, Ishizuka T, Dao ML, Watson JE, Standaert ML, Farese RV (1990) Regulation of protein kinase Cby insulin and diacylglycerol. Biochem Biophys Acta 1054: 95-102

124. Saltiel AR (1987) Insulin generates an enzyme modulator from hepatic plasma membranes: regulation of adenosine $3^{\prime} 5^{\prime}$-monophosphate phosphodiesterase, pyruvate dehydrogenase, and adenylate cyclase. Endocrinology 120: 967-972
125. Saltiel AR, Cuatrecasas P (1986) Insulin stimulates the generation from hepatic plasma membranes of modulators derived from an inositol glycolipid. Proc Natl Acad Sci USA 83: 5793-5797

126. Saltiel AR, Fox JA, Sherkine P, Cuatrecasas P (1986) Insulin stimulated hydrolysis of a novel glycolipid generates modulators of cAMP phosphodiesterase. Science 233: 967-972

127. Mato JM, Kelly KL, Abler A, Jarrett L (1987) Identification of a novel insulin-sensitive glycophospholipid from $\mathrm{H} 35$ hepatoma cells. J Biol Chem 262: 2131-2137

128. Kelly KL, Mato JM, Jarrett L (1986) The polar head group of a novel insulin-sensitive glycophospholipid mimics insulin action on phospholipid methyltransferase. FEBS Lett 209: 238-242

129. Kelly KL, Mato JM, Merida J, Jarrett L (1987) Glucose transport and antilipolysis are differentially regulated by the polar head group of an insulin-sensitive glycophospholipid. Proc Natl Acad Sci USA 84: 6404-6407

130. Alemany S, Mato JM, Stralfors P (1987) Phosphodephosphocontrol by insulin is mimicked by a phosphooligosaccharide in adipocytes. Nature 330: 77-79

131. Standaert ML, Farese RV, Cooper DR, Pollet RJ (1988) Insulininduced glycerolipid mediators and the stimulation of glucose transport in BC3H-1 myocytes. J Biol Chem 263: 8698-8705

132. Mato JM (1989) Insulin mediators revisited. Cell Signal 1: 143-146

133. Garcia de Herreros A, Birnbaum M (1989) The regulation of the glucose transporter gene expression in $3 \mathrm{~T} 3$ adipocytes. $\mathrm{J}$ Biol Chem 264:9885-9890

134. Mückler M (1990) Family of glucose transporter genes. Diabetes 39: 6-11

135. Fukumoto H, Seino S, Imura H et al. (1988) Sequence tissue distribution and chromosomal location of mRNA encoding a novel human glucose transporter-like protein. Proc Natl Acad Sci USA 85: 5434

136. Häring H, Biermann E, Kemmler W (1981) Coupling of insulin binding and insulin action on glucose transport in fat cells. Am J Physiol 240: E556-E565

137. Häring HU, Biermann E, Kemmler W (1982) Relation of insulin receptor occupancy and deactivation of glucose transport. Am J Physiol: E234-E240

138. Cushman SW, Wardzala LJ (1980) Potential mechanism of insulin action on glucose transport in the isolated rat adipose cell. J Cell Biochem 255: 4758-4762

139. Kono T, Suzuki K, Dansey LE, Robinson FW, Blewis TL (1981) Energy-dependent and protein synthesis-independent recycling of the insulin-sensitive glucose transport mechanism in fat cells. J Biol Chem 256: 6400-6407

140. Joost HG, Weber TM, Cushman SW, Simpson IA (1986) Insulin stimulated glucose transport in rat adipose cells. J Biol Chem 261: $10017-10020$

141. Kahn BB, Cushman SW (1987) Mechanism for markedly hyperresponsive insulin-stimulated glucose transport activity in adipose cells from insulin-treated streptozotocin diabetic rats. J Biol Chem 262: 5118-5124

142. Matthaei S, Garvey WT, Horuk R, Hueckstaedt TP, Olefsky JM (1987) Human adipocyte glucose transport system. Biochemical and functional heterogeneity of hexose carriers. J Clin Invest 79: 703-709

143. Karnieli E, Armoni M, Cohen P, Kanter Y, Rafaeloff R (1987) Reversal of insulin resistance in diabetic rat adipocytes by insulin therapy. Restoration of glucose transporters and enhancement of glucose-transport acitvity. Diabetes 36: 925-931

144. Obermaier-Kusser B, Mühlbacher C, Mushack J et al. (1989) Further evidence for a two-step model of glucose-transport regulation. Biochem $\mathbf{J} 261: 699-705$

145. Machicao F, Mushack J, Seffer E, Ermel B, Häring HU (1990) Mannose, glucosamine and inositol monophosphate inhibit the effects of insulin on lipogenesis. Biochem J 266: 909-916

146. Häring HU, White MF, Kahn CR et al. (1984) Abnormality of insulin binding and receptor phosphorylation in an insulin resistant melanoma cell line. J Cell Biol 99:900-908 
147. Häring HU, Obermaier B, Ermel B et al. (1987) Insulin receptor kinase defects as a possible cause of cellular insulin resistance. Diabete Metab 13:284-293

148. LeMarchand Y, Gremeauy T, Ballotti R (1985) Insulin receptor tyrosine kinase is defective in skeletal muscle of insulin-resistant obese mice. Nature 315:676-679

149. Kadowaki T, Kasuga M, Akanuma Y, Ezaki O, Takaku F (1984) Decreased autophosphorylation of the insulin receptor kinase in streptozotocin-diabetic rats. $J$ Biol Chem 259: 1420814216

150. Debant A, Guerre-Millo M, LeMarchand-Brustel Y, Freychet P, Lavar M, VanObberghen E (1987) Insulin receptor kinase is hyperresponsive in adipocytes of young obese Zucker rats. Am J Physiol 252: E273-E278

151. Bray GA (1977) The Zucker fatty rat: a review. Fed Proc 36: $148-153$

152. Crettaz M, Jeanrenaud B (1980) Progressive establishment of insulin resistance in skeletal muscle of obese rats. Congress of Obesity: $268-274$

153. Gremeaux T, Tanti JF, VanObberghen E, LeMarchand-Brustel Y (1987) Alteration of insulin receptor kinase in obese insulinresistant mice. Biochimie 69:387-393

154. Vicario P, Brady EJ, Slater EE, Saperstein R (1987) Insulin receptor tyrosine kinase activity is unaltered in ob/ob and db/dt mouse skeletal muscle membranes. Life Sci 41: 1233-1241

155. Ludwig SM, Müller-Wieland D, Goldstein BJ, Kahn CR (1988) The insulin receptor gene and its expression in insulin resistant mice. Endocrinology 123: 594-600

156. Burant CF, Trentelaar MK, Buse MG (1986) Diabetes induced functional and structural changes in insulin receptors from rat skeletal muscle. J Clin Invest 77: 260-270

157. Grigorescu F, Flier JS, Kahn CR (1984) Defect in insulin receptor phosphorylation in erythrocytes and fibroblasts associated with severe insulin resistance. J Biol Chem 259: 15003-15006

158. Grunberger G, Zick Y, Gordon PH (1984) Defect in phosphorylation of insulin receptors in cells from an insulin-resistant patient with normal insulin binding. Science 223: 932-934

159. Grigorescu F, Flier JS, Kahn CR (1986) Characterization of binding and phosphorylation defects of erythrocyte insulin receptors in the type A syndrome of insulin resistance. Diabetes 35: $127-138$

160. Kadowaki T, Bevins CL, Cama A et al. (1988) Two mutant alleles of the insulin receptor gene in a patient with extreme insulin resistance. Science 240: 787-790

161. Kakahi T, Hisatomi A, Kuzuya H et al. (1988) Defective processing of insulin-receptor precursor in cultured lymphocytes from a patient with extreme insulin resistance. J Clin Invest 81 : 2020-2022

162. Kriauciunas KM, Müller-Wieland D, Reddy SSK, Taub R (1988) Altered expression and function of the insulin receptor in a family with lipatrophic diabetes. J Clin Endocrinol Metab 67: 1284-1293

163. Maassen JA, Klinkhammer MP, Zon GCM Van der et al. (1988) Fibroblasts from a leprechaun patient have defects in insulin binding and insulin receptor autophosphorylation. Diabetologia 31: 612-617

164. Klinkhammer MP, Groen NA, Zon GCM van der et al. (1989) A leucine-to-proline mutation in the insulin receptor in a family with insulin resistance. EMBO J 8: 2503-2525

165. Lekanne Deprez RH, Potter van Loon BJ, Zon GCM van deret al. (1989) Individuals with only one allele for a functional insulin receptor have a tendency to hyperinsulinaemia but not to hyperglycaemia. Diabetologia 32: 740-744

166. Kirsch D, Baumgarten M, Deufel T, Rinninger F, Kemmler W, Häring HU (1983) Catecholamine-induced insulin resistance of glucose transport in isolated rat adipocytes. Biochem J 216: $737-745$

167. Klein HH, Matthaei S, Drenkhan M, Ries W, Scriba PC (1991) The relationship between insulin binding, insulin activation of insulin-receptor tyrosine kinase, and insulin stimulated glucose uptake in isolated rat adipocytes. Biochem J 27: 787-792
168. Tanti JF, Gremeaux T, Rochet NR, VanObberghen E, LeMarchand-Brustel Y (1987) Effect of cyclic AMP-dependent protein kinase on insulin receptor tyrosine kinase activity. Biochem $\mathrm{J}$ 245: 19-26

169. Roth R, Beaudoin J (1987) Phosphorylation of purified insulin receptor by cAMP-kinase. Diabetes 36: 123-126

170. Lewis RE, Czech MP (1987) Phospholipid environment alters hormone-sensitivity of the purified insulin receptor kinase. Biochem J 248: 829-836

171. Ermel B, Vogt B, Obermaier-Kusser B, Häring HU (1989) Hyperglycaemia induced insulin resistance is associated with stimulation of protein kinase $\mathrm{C}$ and inhibition of insulin receptor kinase. Diabetologia 32 [Suppl 1]: 485 (Abstract)

172. Draznin B, Leiter JW, Sussmann KE, Sherman N (1988) Insulin and glucose modulate protein kinase $\mathrm{C}$ activity in rat adipocytes. Biochem Biophys Res Commun 156: 570-575

173. Müller HK, Kellerer M, Ermel B, Mühlhöfer A, ObermaierKusser B, Häring HU (in press) Protein kinase Cinhibitors prevent glucose induced resistance of the insulin receptor tyrosine kinase in rat fat cells. Diabetes

174. Ishizuka T, Hoffman J, Cooper DR, Watson JE, Pushkin DB, Farese RV (1989) Glucose-induced synthesis of diacylglycerol de novo is associated with translocation (activation) of protein kinase C in rat adipocytes. FEBS Lett 249: 234-238

175. Ishizuka T, Cooper DR, Farese RV (1989) Insulin stimulates the translocation of protein kinase $C$ in rat adipocytes. FEBS Lett 257: $337-340$

176. Arsenis G, Livingston JN (1986) Alterations in the tyrosine kinase activity of the insulin receptor produced by in vitro hyperinsulinemia. J Biol Chem 261: 147-153

177. Sweet LJ, Dudley DT, Pessia JE, Spector AA (1987) Phospholipid activation of the insulin receptor kinase: regulation by phosphatidylinositol. FASEB J 1: 55-59

178. Rosen OM, Lebwohl DE (1988) Polylysine activates and alters the divalent cation requirements of the insulin receptor protein tyrosine kinase. FEBS Lett 231: 397-401

179. Klein HH, Ciaraldi TP, Freidenberg GR, Olefsky JM (1987) Adenosine modulates insulin activation of insulin receptor kinase in intact rat adipocytes. Endocrinology 120:2339-2345

180. Morrison BD, Feltz SM, Pessin JE (1989) Polylysine activation of insulin dependent insulin receptor protein kinase. Diabetes 38 [Suppl 2]: 60 (Abstract)

181. Auberger P, Falquerho L, Contreres JO et al. (1989) Characterization of a natural inhibitor of the insulin receptor tyrosine kinase: cDNA cloning, purification, and anti-mitogenic action. Cell 58:631-640

182. Caro JF, Cecchin F, Folli F, Marchini C, Binha MK (1988) Effect of T\&D 3 primary cultures of rat hepatocytes. Horm Metab Res 20:327-332

183. Suthijuroon A, Toth EL, Crockford PM, Ryan EA (1988) Insulin action is altered in hyperthyroidism. Clin Invest Med 11: $435-440$

184. Freidenberg GR, Henry RR, Klein HH, Olefsky JM (1987) Decreased kinase activity of insulin receptors from adipocytes of non-insulin-dependent diabetic subjects. Clin Invest 79: 240-250

185. Freidenberg GR, Reichart D, Olefsky JM, Henry RR (1988) Reversibility of defective adipocyte insulin receptor kinase activity in non-insulin-dependent diabetes mellitus. J Clin Invest 82: 1398-1406

186. Caro JF, Sinha MK, Raju SJ et al. (1987) Insulin receptor kinase in human skeletal muscle from obese subjects with and without non-insulin-dependent diabetes. J Clin Invest 79: 13301337

187. Caro JF, Ittoop O, Pories WJ et al. (1986) Studies on the mechanism of insulin resistance in the liver from humans with non-insulin-dependent diabetes. J Clin Invest 78:249-258

188. Arner P, Pollare T, Lithell H, Livingston JN (1987) Defective insulin receptor tyrosine kinase in human skeletal muscle in obesity and Type 2 (non-insulin-dependent) diabetes mellitus. Diabetologia 30:437-440 
189. Obermaier-Kusser B, White MF, Pongratz D, Su Z, Ermel B, Mühlbacher C, Häring HU (1989) A defective intramolecular autoactivation cascade may cause the reduced kinase activity of the skeletal muscle insulin receptor from patients with non-insulin-dependent diabetes mellitus. J Biol Chem 264: 9497-9564

190. Häring HU, Machicao F, Kirsch D et al. (1984) Protein kinase activity of the insulin receptor from muscle. FEBS Lett 176: 229-234

191. Taylor SI, Marcus-Samuels B, Ryan-Young J, Leventhal S, Elders MJ (1986) Genetics of the insulin receptor defect in a patient with extreme insulin resistance. J Clin Endocrinol Metab 62: $1130-1135$

192. Cox N, Epstein PA, Spielmann RS (1989) Linkage studies on NIDDM and the insulin and insulin receptor genes. Diabetes 38: $653-658$

193. Permutt MA, McGill J, Elbein SC, Province M, Bogardus C (1989) Insulin receptor gene polymorphisms (RFLPs) in American Blacks and Pima Indians: an assessment of the use of RFLPs in evaluating a candidate locus for NIDDM. Proceedings of the $3^{\text {rd }}$ Nordisk Insulin Symposium "Genes and gene products in the development of diabetes mellitus". Elsevier, Amsterdam, pp 249-262

194. Vogt B, Seino W, Whittaker J, Obermaier-Kusser B, Häring HU (1989) Reduced insulin-receptor kinase activity of Type 1 (in- sulin-dependent) diabetic patients is not due to a mutation in exon 20 of the IRK gene. Diabetologia 32:554 (Abstract)

195. Moller DE, Yokota A, Flier JS (1989) Normal insulin receptor cDNA sequence in Pima Indians with NIDDM. Diabetes 38: $1496-1500$

196. Ober C, Xiang KS, Thisted RA, Indovina KA, Wason CJ, Dooley S (1989) Increased risk for gestational diabetes mellitus associated with insulin receptor and insulin like growth factor II restriction fragment length polymorphisms. Genet Epidemiol 6: $559-569$

197. Mosthaf L, Vogt B, Häring HU, Ullrich A (1991) Altered expression of insulin receptor types $A$ and $B$ in the skeletal muscle of non-insulin-dependent diabetes mellitus patients. Proc Natl Acad Sci USA 88: $4728-4730$

198. Bulangu LN, Ossowski VM, Bogardus C, Mott D (1990) Insulin-sensitive tyrosine kinase: relationship with in vivo insulin action in humans. Am J Physiol 258: E964-E974

Dr. H.U.Häring

Institut für Diabetesforschung

Kölner Platz 1

W-8000 München 40

FRG 